\title{
The role of the suckling stimulus in regulating pituitary prolactin mRNA in the rat
}

\author{
Ling Ru Lee ${ }^{1}$, Daniel J. Haisenleder ${ }^{2}$, John C. Marshall ${ }^{2}$ and M. Susan Smith ${ }^{1}$ \\ 'Department of Physiology, School of Medicine, University of Pittsburgh, Pittsburgh, PA 15261, L.S.A., \\ and ${ }^{2}$ Division of Endocrinology and Metabolism, University of Michigan Medical Center, Ann Arbor, MI 48109, U.S.A.
}

(Received 5 November 1988; accepted 27 March 1989)

Key words: Lactation; Prolactin mRNA; Pituitary prolactin; Plasma prolactin

\section{Summary}

Prolactin (PRL) gene expression and the synthesis and secretion of PRL were examined in ovarian-intact lactating rats suckling eight pups on 10 days postpartum. Plasma samples were assayed for PRL concentrations, and pituitary glands were analyzed for total PRL content and PRL mRNA levels. We found that suckling-induced hyperprolactinemia was associated with very high levels of plasma PRL and a doubling in pituitary PRL mRNA levels, whereas pituitary PRL content was not changed. Removal of the suckling pups decreased plasma PRL concentrations 15 -fold within $24 \mathrm{~h}$. 'This decrease in PRL secretion was not accompanied by any significant change in pituitary PRL content. Evidently, both synthesis and secretion of PRL were decreased in the pituitary gland within $24 \mathrm{~h}$ following cessation of suckling, as pituitary PRL mRNA content had returned to diestrous levels at this time. To determine whether or not ovarian steroids might have contributed to the changes in PRL synthesis and secretion during lactation and after withdrawal of the suckling stimulus, the experiments were repeated in lactating rats ovariectomized (OVX) on day 2 postpartum. The results in these OVX rats were qualitatively similar to those described in ovarian-intact rats.

We concluded from these findings that the stimulus of suckling induces increases in PRL mRNA levels in the pituitary which provides for the increased PRL synthesis accompanying increased PRL secretion. The cessation of suckling led to prompt decreases in PRL synthesis and secretion within $24 \mathrm{~h}$.

\section{Introduction}

In the rat, the pattern of plasma prolactin (PRL) during the estrous cycle is similar to that

Address for correspondence: Dr. M. Susan Smith, Department of Physiology. School of Medicine, University of Pittsburgh, Pittsburgh, PA 15261, U.S.A.

These studies were supported by grants from the NIH to M.S.S. (HD 14643), J.C.M. (HD 11489) and D.J.H. (DH 07027) for plasma luteinizing hormone ( $\mathrm{LH})$. Basal PRL and LH are low except on the afternoon of procstrus (Gay et al., 1970; Smith et al., 1975). In the ovariectomized rat, injection of estradiol induces daily afternoon surges of PRL and LH (Neill et al., 1971; Neill, 1972; Carrillo et al., 1987). However, in some physiological conditions, the plasma levels of PRL and of $\mathrm{LH}$ are inversely related. For example, during the first half of pregnancy (Bast et al., 1972; Butcher et al., 1972) and pseudopregnancy (Bast et al., 1972; Smith et al., 1975), during lactation ( $\mathrm{Lu}$ et al., 1976; Fox et al., 1984), and in 
response to stress (Neill, 1970; Ferland et al, 1978; Khorran et al., 1985; Petraglia et al., 1986), plasma PRL is increased while plasma $\mathrm{LH}$ is at low basal levels. Recently, we have shown that LH secretion is suppressed during lactation and pituitary $\alpha$-subunit mRNA and $\mathrm{LH} \beta$ mRNA levels are also decreased (Fox et al., 1984; Lee et al., 1989a). Moreover, when the suckling stimulus is withdrawn by removing the pups, the reappearance of pulsatile $\mathrm{LH}$ secretion is associated with the accumulation of pituitary $\mathrm{LH}$ subunit mRNA (Lee et al., 1989a, b). The present experiments were designed to determine how plasma prolactin concentrations, pituitary PRL content and pituitary PRL mRNA levels are affected by lactation and by withdrawal of the suckling stimulus.

\section{Materials and methods}

\section{Animals}

Female Sprague-Dawley rats from Zivic Miller Laboratories were kept under controlled temperature $\left(20-24^{\circ} \mathrm{C}\right)$ and lighting (lights on $06.00-18.00$ h) conditions. Food and water were provided ad libitum. Rats were mated during proestrus and pregnant animals were placed in maternity cages 2 days before the expected day of parturition. Lactating rats (day of delivery designated day 0 postpartum) were ovarian-intact or were ovariectomized on day 2 postpartum and, at that time, litters were adjusted to 8 or 0 pups. Experiments were conducted on day 10 postpartum, and in some groups, litters were removed $12-72 \mathrm{~h}$ before day 10 .

Blood collection procedures and pituitary gland removal

Rats were decapitated and $5-10 \mathrm{ml}$ of blood were collected into heparinized tubes. Plasma was stored at $-20^{\circ} \mathrm{C}$ until assayed for PRL. Pituitary glands were removed and homogenized in phosphate-buffered saline (PBS) ( $\mathrm{pH} 7.0$ ), then centrifuged at $3000 \times g$ for $30 \mathrm{~min}$. The supernatant was stored at $-20^{\circ} \mathrm{C}$ until assayed for PRL. To assess whether the extraction method affected PRL content (Haggi and Aoki, 1981; Lawson et al., 1987), pituitaries from some groups of animals were extracted in high $\mathrm{pH}$ PBS $(\mathrm{pH} \mathrm{10.5).} \mathrm{The}$ results are expressed as $\mu \mathrm{g}$ PRL $/ 100 \mu \mathrm{g}$ DNA. In our laboratory, pituitary DNA content averages about $100 \mu \mathrm{g}$ /pituitary. For RNA determinations, pituitary glands were removed under sterile conditions, rapidly frozen on dry ice and stored at $-70^{\circ} \mathrm{C}$.

\section{$R N A$ extraction and measurement of $P R L m R N A$}

Pituitaries were quickly thawed and homogenized in $220 \mu \mathrm{l}$ buffer $(10 \mathrm{mM}$ Tris- $\mathrm{HCl}, 0.5 \%$ Nonidet P-40, and $1 \mathrm{mM}$ EDTA, pH 7.4). The homogenate was centrifuged at $13000 \times g$ for 5 min in the cold room. The nuclear pellets were sonicated to assay DNA content (Labarca et al., 1980). The RNA in the supernatant was extracted with a mixture of phenol/chloroform/isoamyl alcohol $(100: 100: 1)$. Total cytoplasmic RNA was quantitated by absorbance at $260 \mathrm{~nm}$ (Papavasiliou et al., 1986). Specific PRL mRNA levels were measured by an RNA dot-blot hybridization as described previously (Papavasiliou et al., 1986), using a rat PRL cDNA probe provided by Dr. Richard A. Maurer (Maurer, 1983). In this study, all samples were measured in the same dot-blot assay. We performed a number of experiments to optimize the dot-blot assay for PRL mRNA. To determine the amount of PRL cDNA probe that was necessary to completely saturate the binding sites per filter, identical quantities of RNA from an adult female rat pool were spotted onto several nitrocellulose filters (1200 ng of RNA spotter per filter) and each filter was hybridized with different concentrations of labeled single-stranded PRL cDNA probe $(25-200 \mathrm{ng} / 6 \mathrm{ml}$ hybridization buffer). Following $16 \mathrm{~h}$ of hybridization, filters were washed and dots cut out and counted for 1 min. The results in Fig. 1 show that under the conditions used, the hybridization of PRL mRNA to cDNA was complete using $100 \mathrm{ng}$ or more probe/filter. We have selected $150 \mathrm{ng}$ cDNA/ 1200 ng RNA spotted as a constant, to ensure saturation in our assay system. Fig. 2 shows that when a saturating amount of PRL probe was used, increasing the quantity of RNA per dot resulted in a linear increase in PRL mRNA per dot. We spot 25 or $50 \mathrm{ng}$ RNA per dot in triplicate for each sample in our optimized assay system.

During the characterization of the PRL mRNA dot-blot assay, we compared dot blots to Northern 


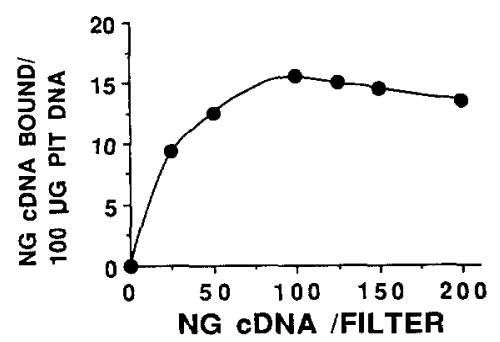

Fig. 1. Determination of saturating concentrations of PRL cDNA probe for a constant amount $(1200 \mathrm{ng})$ of total cytoplasmic RNA per nitrocellulose filter. Each point represents triplicate measurements. (Note: in our assay system we spot $1200 \mathrm{ng}$ of RNA per filter (25 or $50 \mathrm{ng}$ RNA per blot) and hybridize to $150 \mathrm{ng}$ of PRL cDNA, to insure saturation.)

blot analysis using mRNA samples from several rat models (intact males, OVX females, cycling females). In general, PRL mRNA levels determined by dot-blot analysis showed parallel changes to samples examined by Northern blot. Also, the PRL cDNA probe selectively hybridized to a single mRNA band. Results are expressed as ng cDNA bound $/ 100 \mu \mathrm{g}$ pituitary DNA to equalize variations in pituitary size and cell number between samples. The equation used to calculate the results is as follows:

ng probe bound $/ 100 \mu \mathrm{g}$ pituitary DNA

$$
=\frac{A \times R \times 1.22 \times 100}{\mathrm{SA} \times e^{-k t} \times C \times D} \times 10^{3}
$$

where $A$ is the counts per min specifically bound, $R$ is the pituitary RNA content $(\mu \mathrm{g} / 180 \mu 1$ cytosol), 1.22 is a volume correction factor for the

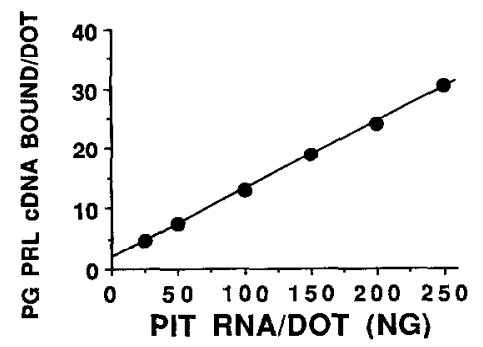

Fig. 2. The linearity of the PRL cDNA binding to increasing amounts of total cytoplasmic RNA per dot (from a random cycling female rat pituitary pool), when a saturating amount of cDNA was applied to a nitrocellulose filter and hybridized (each point is the result of triplicate determinations). difference between the volume of homogenization $(220 \mu 1)$ and the volume of phenol-extracted cytosol $(180 \mu 1), \mathrm{SA}$ is the specific activity of the probe (ranged between $2-5 \times 10^{8} \mathrm{cpm} / \mu \mathrm{g}$ PRL cDNA), $e^{-k t}$ is the correction factor for radioactive decay, where $t$ is the time difference in days between the data of nick translation and counting of the nitrocellulose spots and $k$ is the ${ }^{32} \mathrm{P}$ decay constant (0.0485), $C$ is RNA ( $\mu$ g per spot), $D$ is the pituitary DNA content $(\mu \mathrm{g})$, and $10^{3}$ is the mass conversion constant from micrograms to nanograms (Papavasiliou et al., 1986).

\section{Prolactin radioimmunoassay and data analysis}

Plasma PRL concentrations (5-20 $\mu 1$ duplicates from each sample) and pituitary PRL content ( $1: 1000$ dilution, 5-10 $\mu 1$ duplicates) were assessed by the radioimmunoassay (RIA) described previously (Smith, 1978a). NIAMD RP-3 standard was used, and the sensitivity of the assay was 0.01 $\mathrm{ng} /$ tube. The data were analyzed by one-way analysis of variance and Newman-Keuls test $(P<$ $0.05)$.

\section{Results}

Plasma prolactin levels, and pituitary prolactin content in ovarian-intact rats during lactation and after withdrawal of the suckling stimulus

Fig. 3 shows that the suckling stimulus from eight pups increased plasma PRL concentrations by 15 -fold when compared to control, diestrous rats $(99.2 \pm 6.3$ vs. $6.3 \pm 1.8 \mathrm{ng} / \mathrm{ml})$. At $24 \mathrm{~h}$ after pup removal, plasma PRL concentrations had dropped sharply and were not significantly different from diestrous, control values. Pituitary PRL content was similar in lactating rats and in diestrous rats $(22.1 \pm 4.3$ vs. $26.8 \pm 4.2 \mu \mathrm{g} / 100 \mu \mathrm{g}$ DNA). After pup removal, pituitary PRL content did not change significantly compared to lactating rats. Table 1 shows the effect of extraction at a high $\mathrm{pH}$ on pituitary PRL content. Animals whose pups had been removed for $48 \mathrm{~h}$ were included to more carefully determine the effect of withdrawal of the suckling stimulus. Increasing the $\mathrm{pH}$ of the homogenization buffer from 7.0 to 10.5 resulted in about a 10 -fold increase in PRL content (see Fig. 3 for comparison). However, qualitatively, the results were very similar to those shown in Fig. 3. 


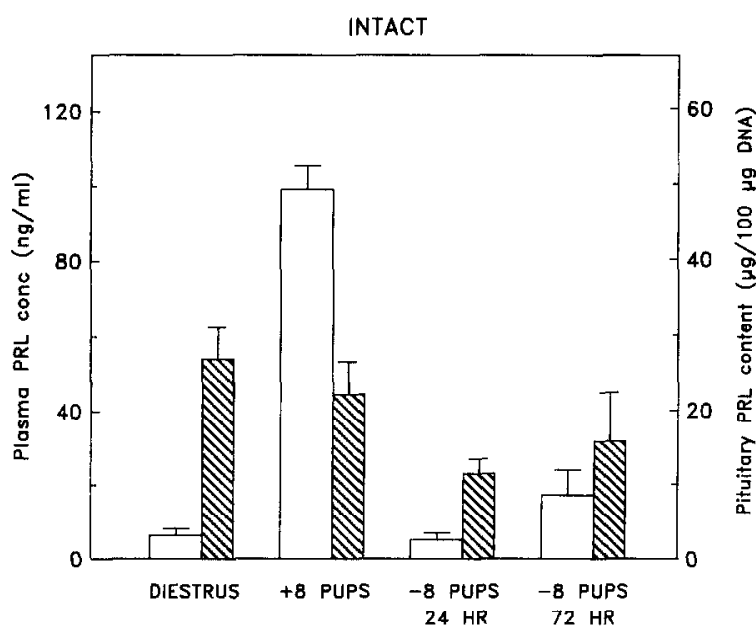

Fig. 3. The effect of lactation and of withdrawing the suckling stimulus on plasma PRL levels (open columns) ( $n=6-13$ animals) and pituitary PRL content (hatched columns) ( $n=$ 3-6 animals) in ovarian-intact rats on day 10 postpartum. Plasma PRL was significantly higher $(P<0.05)$ in the +8 pup group than in any other group.

There was no significant change in pituitary PRL content after pup removal.

\section{Prolactin $m R N A$ concentrations in ovarian-intact lactating rats and after pup removal}

Pituitary PRL mRNA levels in diestrous rats $(n=8)$ averaged $6.7 \pm 0.3 \mathrm{ng} \mathrm{cDNA} / 100 \mu \mathrm{g}$ pituitary DNA (Fig. 4). During lactation, the mRNA levels increased to $14.6 \pm 0.9 \mathrm{ng}$ cDNA $/ 100 \mu \mathrm{g}$ pituitary DNA. By $24 \mathrm{~h}$ after pup removal, pituitary PRL mRNA levels had returned to diestrous, control levels.

TABLE 1

EFFECT OF HIGH $\mathrm{pH}$ HOMOGENIZATION BUFFER (PBS, pH 10.5) ON PITUITARY PRL CONTENT

Numbers are mean \pm SEM.

\begin{tabular}{ll}
\hline Group & $\begin{array}{l}\text { Pituitary PRL } \\
(\mu \mathrm{g} \text { PRL } / 100 \mu \mathrm{g} \mathrm{DNA})\end{array}$ \\
\hline Dicstrus & $216 \pm 18^{\mathrm{a}}$ \\
Intact +8 pups & $159 \pm 18$ \\
Intact -8 pups, 24 h & $152 \pm 18$ \\
Intact -8 pups, 48 h & $150 \pm 9$
\end{tabular}

${ }^{a} P<0.05$ compared to other groups.

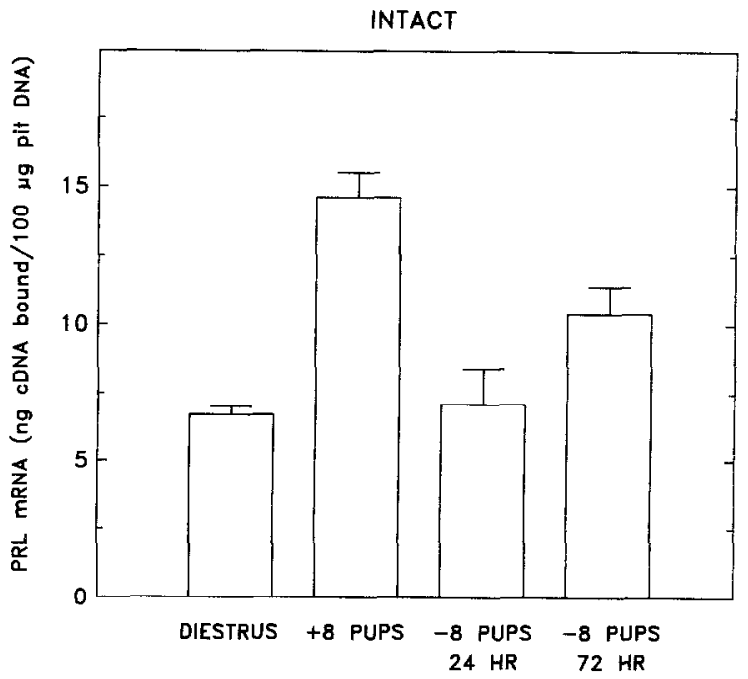

Fig. 4. Pituitary PRL mRNA content in ovarian-intact lactating rats on day 10 postpartum ( $n=6-8$ animals). PRL mRNA levels were significantly increased by the suckling stimulus compared to the other groups and had returned to diestrous levels $24 \mathrm{~h}$ after pup removal.

Plasma prolactin levels and pituitary prolactin content in ovariectomized lactating rats and after withdrawal of the suckling stimulus

Lactation increased plasma PRL concentrations to $119 \pm 12 \mathrm{ng} / \mathrm{ml}$ (Fig. 5), levels similar to

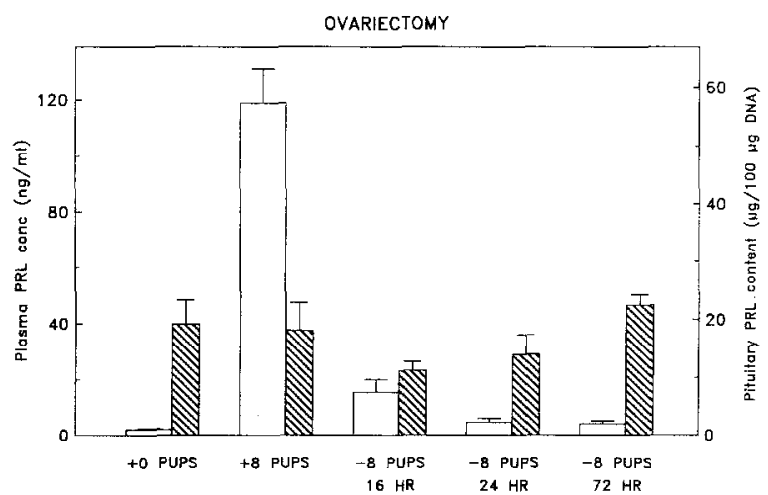

Fig. 5. The effect of lactation and of withdrawing the suckling stimulus on plasma PRL levels (open columns) and pituitary PRL content (hatched columns) in OVX lactating rats on day 10 postpartum ( $n=4-7$ animals). Ovariectomy was performed on day 2 postpartum. Suckling greatly increased plasma PRL concentrations when compared to all other groups. Plasma PRL had returned to nonsuckled control levels by $16 \mathrm{~h}$ after pup removal. Pituitary PRL content did not differ among these groups. 


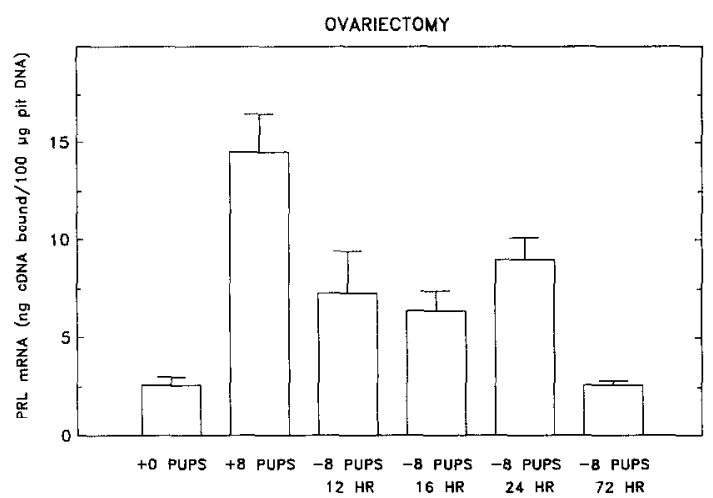

Fig. 6. Pituitary PRL mRNA during lactation and after pup removal in OVX rats ( $n=6-10$ animals). Pituitary PRL mRNA levels were increased significantly by suckling. PRL mRNA levels had decreased by $12 \mathrm{~h}$ after pup removal but did not return to nonsuckled control levels until $72 \mathrm{~h}$.

those observed in ovarian-intact lactating rats (Fig. 3). Plasma PRL concentrations had decreased markedly by $16 \mathrm{~h}$ after pup removal, to levels not significantly different from levels observed in OVX +0 animals. Pituitary PRL content in the OVX lactating rat $(19.2 \pm 4.2 \mu \mathrm{g} / 100 \mu \mathrm{g}$ DNA) was similar to the content observed in intact lactating rats $(26.8 \pm 4.2 \mu \mathrm{g} / 100 \mu \mathrm{g}$ DNA). Pituitary PRL content did not change in the presence of the suckling stimulus (Fig. 5), and similar to the intacl rats, did not change significantly after pup removal. The primary differences between intact and OVX animals was that plasma PRL was significantly higher in diestrous controls and at $72 \mathrm{~h}$ after pup removal than in comparable OVX groups.

Pituitary prolactin $m R N A$ concentrations in $O V X$ lactating rats and after pup removal

Ovariectomized nonsuckling rats had low pituitary PRL mRNA content than diestrous rats $(2.6$ \pm 0.4 vs. $6.7 \pm 0.3 \mathrm{ng}$ cDNA bound $/ 100 \mu \mathrm{g}$ pituitary DNA, Figs. 5 and 6). The suckling stimulus increased pituitary PRL mRNA in OVX rats to the same levels as in ovarian-intact lactating rats $(14.5 \pm 2.0$ vs. $14.6 \pm 0.9$ ng cDNA bound $/ 100 \mu \mathrm{g}$ pituitary DNA) (Figs. 5 and 6). By $12 \mathrm{~h}$ after pup removal, PRL mRNA content had decreased when compared to lactating rats suckling eight pups. By $72 \mathrm{~h}$, pituitary PRL mRNA $(2.6 \pm 0.2 \mathrm{ng}$ cDNA bound $/ 100 \mu \mathrm{g}$ pituitary DNA) had returned to the levels observed in nonlactating control rats. These levels were significantly lower than those observed at $72 \mathrm{~h}$ after pup removal in intact animals.

\section{Discussion}

During lactation, we observed very high plasma PRL levels which correlated with high pituitary PRL mRNA levels. Moreover, plasma PRL and pituitary PRL mRNA were increased to the same degree in both OVX and ovarian-intact lactating rats. We have shown previously that plasma estrogen concentrations are very low during lactation (Smith, 1978b; Lee et al., 1989b). Thus, it appears that estrogen does not play a role in increasing PRL synthesis during lactation. Therefore, the mechanisms mediating PRL synthesis during lactation are different from those during other conditions such as the estrogen-induced PRL surge. Recently, Carrillo et al. (1987) reported that estrogen-induced PRL surges are associaled with very high levels of pituitary PRL and PRL mRNA content, suggesting that estrogen increases PRL synthesis. Estrogen is known to have a stimulatory effect on pituitary PRL gene expression and on PRL synthesis in vivo and in vitro (Maurer, 1982; Shull and Gorski, 1984). Our data did show that basal levels of plasma PRL and pituitary mRNA content were significantly higher in intact animals, i.e., diestrous controls and at $72 \mathrm{~h}$ after pup removal, than in the OVX animals, which is probably due to much higher levels of plasma estradiol in the intact animals.

In investigating the time course of the decline in PRL secretion and the change in pituitary PRL stores following withdrawal of suckling pups from the lactating rat, our findings show that in both OVX and intact lactating rats, the return to basal levels of plasma PRL and of pituitary PRL mRNA occurred within 12-24 h after pup removal. Surprisingly, pituitary PRL content remained quite constant in the face of very high or low plasma PRL concentrations and PRL mRNA levels. These data differ from those of Torres and Aoki (1985) who reported that PRL content was increased 24 $\mathrm{h}$ after withdrawal of suckling. However, our data consistently showed that PRL content tended, if anything, to decrease $12-24 \mathrm{~h}$ after pup removal, 
whether in intact or OVX rats, and regardless of the $\mathrm{pH}$ of the homogenization buffer. Therefore, our results cannot be explained by a failure to adequately extract PRL. It has been reported that within $24 \mathrm{~h}$ after pup removal there is a marked increase in pituitary lysosomal enzyme activity and prolactin protease, which would cause lysosomal degradation of PRL (Farquhar, 1977; De Marco et al., 1982). This crinophagy could prevent large increases in PRL content in the face of decreases in synthesis and secretion. Perhaps, if these parameters were studied during a dynamic episode of suckling-induced PRL secretion, instead of during steady-state conditions as examined in this study, changes in PRL content would be observed. It has been reported that during the proestrous PRL surge (Haisenleder et al., 1988) and during the estrogen-induced PRL surge (Carrillo et al., 1987), periods of dynamic increases in PRL secretion, pituitary PRL content decreases and PRL mRNA levels increase. In this situation, PRL synthesis does not appear to be able to keep up with the secretion of PRL.

What factors may be involved in increasing pituitary PRL mRNA levels during lactation? One hypothesis is that suckling induces pituitary PRL secretion which in turn triggers pituitary PRL synthesis. That there may be a relationship between PRL gene expression and PRL secretory pools is supported by studies of the PRL proestrous surge. When the PRL surge is blocked by bromocriptine, the decrease in pituitary PRL content and the increase in pituitary PRL mRNA are not observed (Haisenleder et al., 1988), suggesting that PRL secretion triggers increases in PRL mRNA levels. Another hypothesis is that suckling increases the secretion of prolactin-releasing factors (PRFs), such as thyrotropin-releasing hormone (TRH) (Grosvenor and Mena, 1980; Horn et al., 1985: Rondeel et al., 1988), oxytocin (Samson et al., 1986) and vasoactive intestinal peptide (VIP) (Abe et al., 1985), which act to increase PRL synthesis and PRL secretion. In fact, the secretagogue action of TRH (Rosenfeld et al., 1983), VIP (Carrillo et al., 1985) and $\mathrm{Ca}^{2+}$ (Jackson and Bancroft, 1988) are associated with increased PRL gene transcription. In addition, suckling-induced suppression of dopamine secretion could increase sensitivity of the lactotrope to PRFs
(De la Escalera and Weiner, 1988) as well as increase PRL mRNA levels, since dopamine has been shown to inhibit PRL gene expression, and decrease PRL mRNA levels (Maurer, 1982). The mechanisms involved in the regulation of $\mathrm{PRL}$ gene expression and PRL secretion during lactation await further study.

In summary, these data show that during lactation and after withdrawal of the suckling stimulus, plasma PRL concentrations and pituitary PRL mRNA levels increase and decrease in parallel, whereas pituitary PRL content remains quite constant. In addition, increases in plasma PRL concentrations and pituitary PRL mRNA in ovarianintact and OVX lactating rats are similar, suggesting that ovarian factors do not play a significant role in regulating these parameters during lactation.

\section{Acknowledgements}

Materials for the prolactin RIA were provided by the National Hormone and Pituitary Agency. The cDNA probe for rat PRL mRNA was provided by Dr. Richard Maurer. We greatly appreciate the technical assistance of Kim Scarnati in these studies.

\section{References}

Abe, H., Engler, D., Molitch, M.E., Bollinger-Gruber, J. and Reichlin, S. (1985) Endocrinology 116, 1383-1390.

Bast, J.D. and Melampy, R.M. (1972) Endocrinology 91, 1499-1505.

Blake, C.A. (1974) Endocrinology 94, 503-508.

Carrillo, A.J., Pool, T.B. and Sharp. Z.D. (1985) Endocrinology $116,202-206$.

Carrillo, A.J., Sharp, Z.D. and DePaolo, L.V. (1987) Endocrinology 121, 19931999.

De la Escalera, G.M. and Weiner. R.I. (1988) Neuroendocrinology $47,186-193$.

De Marco, L., Mashiter, K. and Peters. T.J. (1982) Endocrinology $110,1178-1182$.

Farquhar, M.G. (1977) in Comparative Endocrinology of Prolactin (Dellman, H.D., Johnson, J.A. and Klachko, D.M., eds.), pp. 37-94, Plenum Press, New York.

Ferland, L., Kledzik, G.S., Cusan, L. and Labrie, F. (1978) Mol. Cell. Endocrinol. 12, 267-272.

Fox, S.R. and Smith, M.S. (1984) Endocrinology 115 , 2045-2051

Grosvenor, C.E. and Mena, F. (1980) Endocrinology 107, 863-868. 
Haggi, E. and Aoki, A. (1981) Acta Endocrinol. 97, 338-342. Haisenleder, D.J., Ortolano, G.A., Landefeld, T.D., Zmeili, S.M. and Marshall, J.C. (1989) Endocrinology 124, 2023-2028.

Horn, A.M., Fraser, H.M. and Fink, G. (1985) J. Endocrinol. 104, 205-209.

Jackson, A.E and Bancroft, C. (1988) Endocrine Society Meeting (Abstract 85).

Khorran, O., Bedran DeCastro, J.C. and McCann, S.M. (1985) Endocrinology 117, 2483-2489.

Labarca, C. and Paigen, K. (1980) Anal. Biochem. 102, 344-352.

Lawson, D.M., Haisenleder, D.J., Gala, R.R. and May, J.A. (1987) J. Endocrinol. 113, 71-80.

Lee, L.R., Haisenleder, D.J., Marshall, J.C. and Smith, M.S. (1989a) Endocrinology 124, 776-782.

Lee, L.R., Haisenleder, D.J., Marshall, J.C. and Smith, M.S. (1989b) Endocrinology (in press).

Lu, K.H., Chen, H.T., Huang, H.H., Grandison, L., Marshall, S. and Meites, J. (1976) J. Endocrinol. 68, 241-250.

Maurer, R.A. (1981) Nature 294, 94-97.

Maurer, R.A. (1982) J. Biol. Chem. 257, 2133-2136.
Maurer, R.A. (1983) Biol. Reprod. 28, 27- 35.

Neill, J.D. (1970) Endocrinology 87, 1192-1197.

Neill, J.D. (1972) Endocrinology 90, 1154-1159.

Neill, J.D., Freeman, M.E. and Tillson, S.A. (1971) Endocrinology $89,1448-1453$.

Papavasiliou, S.S., Zmeili, S., Herbon, L., Duncan-Weldon, J., Marshall, J.C. and Landefeld, T.D. (1986) Endocrinology 119, 691-698.

Petraglia, F., Vale, W. and Rivier, C. (1986) Endocrinology 119, 2445-2450.

Rondeel, J.M.M., de Greef, W.J., Visser, T.J. and Voogt, J.L. (1988) Neuroendocrinology 48, 93-96.

Rosenfeld, M.G., Amara, S.G., Birnberg, N.C., Mermod, J.-J. and Murdoch, G.H. (1983) Recent Prog. Horm. Res. 39, 305-351.

Samson, W.K., Lumpkin, M.D. and McCann, S.M. (1986) Endocrinology 119, 554-560.

Shull, J.D. and Gorski, J. (1984) Endocrinology 114, 1550-1557.

Smith, M.S. (1978a) Biol. Reprod. 19, 77-83.

Smith, M.S. (1978b) Endocrinology 102, 114-120.

Torres, A.I. and Aoki, A. (1985) J. Endocrinol. 105, 219-225. 